\title{
INTRODUKSI PROSES PENGOLAHAN PANGAN BERBASIS TANAMAN HORTIKULTURA UNTUK PEMBERDAYAAN MASYARAKAT DESA WUNUT KABUPATEN KLATEN
}

\author{
Danar Praseptiangga, Siswanti, dan Edhi Nurhartadi ${ }^{1)}$ \\ ${ }^{1)}$ Program StudillmudanTeknologiPangan \\ FakultasPertanian, Universitas Sebelas Maret Surakarta \\ email: dpraseptiangga@staff.uns.ac.id
}

\begin{abstract}
Wunut Village is located in Tulung Sub-District, Klaten Regency which has the horticultural potential such as tomato and chili. But the huge potential has not been able to lift the economy of the village community. Therefore the community devotion team of Department of Food Science and Technology, Faculty of Agriculture, Sebelas Maret University chose Wunut Village as the target village. The problems faced by farming communities in Wunut Village are (1) production of chili and tomatoes are abundant, but the selling price is relatively low; (2) the large number of poor people; (3) lack of knowledge and community insight about entrepreneurship in the field of food; (4) interest in entrepreneurship is still lacking in society; And (5) the difficulty of marketing the resulting product. The solutions offered by the community devotion team are through training activities and the introduction of tomato processing technology into "torakur"; Training and introduction of production process technology of shredded pepper; Entrepreneurship training and food industry management; Information technologybased marketing training and direct selling strategies. In order to support these activities, aids were also provided to improve the quality of the chakra and the resulting chili pepper. Equipment provided in the form of cabinet dryer, dry mill, and packer sealer. The result of this activity in the form of introduction of tomato processing technology into "torakur", and processing of chili into shredded chili has been done well, with products that can be accepted by society and have a big prospect to be developed.
\end{abstract}

Keywords:entreprenuership, quality, torakur, shredded chili, Wunut Village 


\begin{abstract}
ABSTRAK
Desa Wunut merupakan suatu desa yang berlokasi di Kecamatan Tulung Kabupaten Klaten. Potensi sumber daya pertanian, khususnya hortikultura, yang tersedia secara melimpah, mendorong Dosen Ilmu dan Teknologi Pangan (ITP), Universitas Sebelas Maret (UNS) Surakarta bekerja bersama dengan Himpunan Mahasiswa Teknologi Pertanian (HIMAGHITA) menjadikannya sebagai desa binaan. Permasalahan yang diprioritaskan untuk diselesaikan di Desa Wunut ini adalah (1) melimpahnya produksi cabai dan tomat namun memiliki harga jual yang relatif rendah; (2) jumlah masyarakat miskin yang masih banyak; (3) kurang sosialisasi pengetahuan dan wawasan masyarakat tentang ilmu berwirausaha, khususnya dalam bidang pangan; (4) minat berwirausaha masih kurang di masyarakat; serta (5) usaha yang sudah berjalan, kurang berhasil karena masalah pemasaran. Solusi yang ditawarkan dari tim pengabdian antara lain dengan melalui kegiatan: pelatihan dan introduksi teknologi pengolahan tomat menjadi torakur; pelatihan dan introduksi teknologi proses produksi abon cabai; training kewirausahaan dan manajemen industri pangan; pelatihan pemasaran berbasis IT dan strategi direct selling. Guna menunjang kegiatan tersebut juga dilakukan pemberian bantuan alat untuk peningkatan mutu dari torakur dan abon cabai yang dihasilkan. Peralatan yang diberikan berupa cabinet dryer, drymill, serta alat pengemas sealer. Hasil kegiatan pengabdian berupa introduksi teknologi pengolahan tomat menjadi torakur, dan pengolahan cabai menjadi abon cabai telah terlaksana dengan baik, dengan produk yang dapat diterima masyarakat dan memiliki prospek besar untuk dikembangkan
\end{abstract}

Kata kunci: abon cabai, Desa Wunut, pemberdayaan, torakur, hortikultura 


\section{PENDAHULUAN}

Desa Wunut berlokasi di Kecamatan Tulung, Kabupaten Klaten dengan luas lahan pertanian sekitar 17 ha atau mencakup $70 \%$ dari luas desa secara keseluruhan.Menurut topografi, Kabupaten Klaten terbagi menjadi 3 dataran yaitu dataran lereng Gunung Merapi, dataran rendah, dan dataran pegunungan kapur. Dengan ketinggian wilayah terbanyak (83,52\%) terletak diantara 100-500 meter di atas permukaan laut (Anonim, 2016), sumber daya pertanian di Kabupaten Klaten tersedia secara melimpah.

Salah satu komoditas unggulan Desa Wunut adalah tomat dan cabai. Setiap musim panen, tomat segar dan cabai yang dihasilkan desa Wunut berturut-turut dapat mencapai 750 kg dan 450 kg. Hasil hortikultura tersebut hanya untuk konsumsi rumah tangga dan dijual langsung kepada konsumen dalam bentuk segar dengan harga yang murah. Harga tomat dijual Rp 3.500/kg. Jika musim panen tiba, harga tomat dapat anjlok di pasaran.
Rendahnya harga tomat tersebut sebenarnya dapat diatasi dengan inovasi proses menjadi produk olahan hortikultura bernilai jual lebih tinggi, seperti olahan tomat berupa torakur dan olahan cabai menjadi produk abon cabai. Namun, karena adanya keterbatasan pengetahuan dan wawasan masyarakat tentang teknologi pengolahan hasil pertanian dan ilmu berwirausaha, potensi besar ini belum dikembangkan oleh masyarakat Desa Wunut.

Padahal di desa tersebut telah terdapat kelompok tani dan karang taruna yang telah terstruktur dengan baik. Selain itu, sumber daya manusia di Desa Wunut sangat potensial untuk dikembangkan. Secara demografi, desa Wunut terdiri dari sekitar 2265 penduduk dengan jenis kelamin laki-laki sebanyak 986 orang dan perempuan sebanyak 1279 orang. Berdasarkan penduduk yang berusia produktif (20-60 tahun) diketahui mayoritas penduduk merupakan petani dan buruh tani (42\%), pegawai negeri dan karyawan swasta (28\%), pekerja serabutan (9\%), dan 
sisanya sebanyak $21 \%$ adalah pengetahuan dan wawasan masyarakat pengangguran.

tentang ilmu berwirausaha, khususnya

Melihat potensi besar tersebut dalam bidang pangan; (4) minat serta atas permintaan langsung dari berwirausaha masih kurang di salah satu tokoh masyarakat, Desa Wunut dipilih sebagaidesa binaan. Sinergi antara Dosen dengan Himpunan Mahasiswa Teknologi Pertanian masyarakat; serta (5) usaha yang sudah berjalan, kurang berhasil karena masalah pemasaran.

Sebagai upaya untuk (HIMAGHITA) Universitas Sebelas Maret menyelesaikan masalah tersebut, tim (UNS) Surakarta diharapkan akan dapat Dosen UNS dengan didukung oleh mengoptimalkan program penerapan HIMAGHITA serta disetujui oleh Kades ipteks dan pemberdayaan masyarakat Wunut, Kelompok Tani "Sumber Rejeki", di Desa Wunut, sehingga cita-cita untuk dan Kelompok Wanita Tani "Dahlia" sebagai mitra kegiatan akan menyelenggarakan program mempunyai nilai ekonomi yang tinggi dapat tercapai.

Introduksi teknologi pengeringan cabai

Dari seluruh permasalahan yang (cabai bubuk kering) dan pengolahan teridentifikasi, telah disepakati bersama antara tim Dosen UNS, masyarakat Desa Wunut, dan HIMAGHITA bahwa beberapa permasalahan yang diprioritaskan untuk diselesaikan adalah: (1) melimpahnya produksi abon cabai; (2) Introduksi teknologi produksi olahan tomat (tomat rasa kurma); (3) Pelatihan kewirausahaan dan manajemen industri pangan; (4) Pelatihan pemasaran berbasis IT dan strategi direct selling.

hortikultura yang belum mampu mensejahterakan masyarakat akibat harga jual yang relatif rendah; (2) jumlah masyarakat miskin yang masih banyak; (3) kurang sosialisasi

\section{METODE/APLIKASI}

Kegiatan pengabdian IbM ini dilaksanakan pada bulan Mei 2015 di Desa Wunut, Kecamatan Tulung, 
Kabupaten Klaten. Solusi yang abon cabai, cabai bubuk kering ditawarkan untuk mengatasi dicampurkan dengan rempah dan permasalahan-permasalahan tersebut bumbu kemudian disangrai. Sedangkan adalah sebagai berikut:

peralatan proses yang dibutuhkan

1. Introduksi teknologi pengeringan untuk proses pengeringan cabai dan cabai (cabai bubuk kering) dan pengolahan abon cabai

pengolahan abon cabai adalah cabinet dryer, mesin penggiling (disk mill), dan Latar belakang dari pengolahan alat penyangrai. Setelah pelatihan cabai bubuk kering dan abon cabai adalah harga jual cabai yang anjlok pada saat panen raya.Pelatihan ini juga menghasilkan produk baru yang masih belum terlalu familiar dimasyarakat Desa Wunut. Cabai kering merupakan olahan cabai yang telah melewati proses pengeringan (Sudaro dan Dwi, 1999). Keunggulan cabai kering dan abon cabai dibandingkan dengan cabai segar antara lain kadar airnya lebih rendah, lebih awet, lebih mudah didistribusikan, dan lebih luwes penggunaannya. Dengan demikian nilai ekonomi cabai akan semakin meningkat. Tahapan proses pembuatan cabai bubuk kering adalah pembersihan, pembelahan, blanching pada larutan sulfit, pengeringan, penggilingan, dan pengemasan. Untuk proses pembuatan selesai dilakukan oleh tim dari ITP UNS, maka beberapa alat yang digunakan akan dihibahkan ke masyarakat untuk menjamin keberlanjutan dari hasil kegiatan ini, yaitu dengan membentuk unit usaha pengeringan cabai dan pengolahan abon cabai di Desa Wunut.

2. Introduksi teknologi produksi olahan tomat (tomat rasa kurma)

Tanaman tomat merupakan salah satu jenis tanaman hortikultura yang strategis dan tergolong sayuran kedua terbesar setelah kentang. Tomat mudah mengalami kerusakan jika tidak disimpan pada kondisi yang baik. Kandungan air dan komponen pektin yang tinggi pada buah tomat, menyebabkan komoditas ini mudah mengalami kerusakan fisik, kimia 
maupun mikrobiologis. Salah satu seperti kurma atau di dalam oven alternatif yang dapat dilakukan untuk hingga kering (Dewanti, dkk, 2010).

mencegah kerusakan buah tomat yaitu mengolahnya menjadi berbagai produk olahan, salah satunya adalah tomat rasa kurma.

Tomat rasa kurma (torakur) merupakan salah satu produk olahan tomat yang menarik dan banyak diminati masyarakat. Teknologi pengolahan cukup sederhana dan relative mudah. Pembuatan tomat rasa kurma dilakukan dengan cara merendam tomat dengan $\mathrm{CaCO}_{3}$ selama 1-2 jam, kemudian tomat ditekan hingga biji keluar, dibelah menjadi dua kemudian bijinya dibuang. Tomat kemudian dicuci hingga bersih, kemudian ditaburkan gula pasir di atasnya dengan perbandingan $(2 \mathrm{~kg}$ tomat : $1 \mathrm{~kg}$ gula). Tomat selanjutnya ditutup dan didiamkan selama semalam hingga keluar air. Setelah itu dilakukan pemasakan tomat dengan api kecil hingga air habis dan kering kemudian didinginkan. Tahap akhir adalah pengeringan tomat di atas terik matahari selama 2-3 hari hingga kering

3. Pelatihan kewirausahaan dan manajemen industri pangan

Berdirinya industri, merupakan wujud dari keberlanjutan program IbM yang dilakukan oleh tim ITP UNS. Adanya industri pangan ditujukan untuk meningkatkan kemandirian masyarakat desa dalam mengembangkan dan meningkatkan ekonomi. Industri tersebut dilakukan dengan memberdayakan SDM serta potensi alam yang ada sehingga diperoleh produk yang memiliki nilai komersial. Produk utama dari industri yang akan didirikan adalah cabai kering, abon cabai, dan olahan tomat (tomat rasa kurma) yang merupakan produk dari program pelatihan sebelumnya. Materi pokok yang akan diberikan dalam kegiatan ini antara lain:

a. Pelatihan motivasi wirausaha bagi para pemuda

b. Penanganan pasca panen

c. Good Manufacturing Practices (GMP) cabai bubuk kering, abon 
cabai, dan olahan tomat(tomat rasa kurma)

d. Sanitasi dan keamanan pangan industri berbasis hasil pertanian

e. Pengendalian mutu produk pangan

f. Pelatihan pengemasan produk pangan

g. Analisis ekonomi industri pangan skala kecil

h. Manajemen dan pembukuan industri pangan skala kecil

i. Teknologi pemanfaatan limbah industri pangan

Setelah pelatihan selesai, maka tim UNS akan terus melakukan pendampingan sejak pengurusan perijinan produksi P-IRT hingga pendampingan produksi dan pemasaran, untuk menjamin stabilitas dan kontinuitas usaha.

4. Pelatihan pemasaran berbasis TI dan strategi direct selling

Dasar dari pelatihan pemasaran ini adalah pemanfaatan TI (Teknologi Informasi) dengan maraknya jejaring sosial yang tersedia. Banyaknya bisnis online serta banyaknya pengguna jejaring social membuat pemasaran produk di dunia maya menjadi salah satu cara yang efektif. Pelatihan pemanfaatan jejaring sosial (sosial media), seperti facebook, pembuatan blog, dan pemasangan iklan dengan menampilkan produk-produk akan sangat membantu untuk perkembangan UKM yang ada di Desa Wunut. Pemasaran dengan pemanfaatan $\mathrm{TI}$ ini sangat menguntungkan sebab produk tidak hanya dikenal disekitar lingkungan tetapi mampu dikenali oleh masyarakat luas. Pelatihan ini akan berjalan apabila warga (anggota UKM) di Desa Wunut mengetahui tentang bisnis online dan terampil dalam pengelolaan jejaring tersebut. Target utama pelatihan pemasaran dengan $\mathrm{TI}$ adalah pemuda, sedangkan produk utama yang dipasarkan dengan $\mathrm{TI}$ adalah cabai kering, abon cabai, dan tomat rasa kurma. Materi utama pada pelatihan ini adalah blog, web developing, dan pengelolaannya. Sedangkan untuk strategi direct selling yang utamanya akan disampaikan adalah motivasi dan teknik negosiasi. 
Strategi yang diterapkan untuk menjamin keberhasilan dari berbagai program pada kegiatan ini adalah:

1. Mencarikan pasar produk cabai kering, abon cabai, dan tomat rasa kurma terlebih dahulu, agar keberlangsungan pemasaran dapat terjamin. Jika penjualan dan keuntungan dari pembuatan cabai kering, abon cabai, dan tomat rasa kurma telah jelas (dan lebih besar dari pendapatan mereka selama ini), para petani dan peserta pelatihan pada umumnya akan bersemangat untuk mengikuti program pengabdian yang ditawarkan.

2. Peralatan yang digunakan sebagai alat pelatihan akan dihibahkan ke kelompok tani, sehingga tidak ada kendala lagi kendala modal usaha bagi para petani.

\section{Menggandeng} Himpunan Mahasiswa Teknologi Pertanian (HIMAGHITA) UNS adalah merupakan salah satu jaminan bahwa keberlangsungan kegiatan ini akan berkelanjutan. Sebab kegiatan ini sesuai dengan program yang telah ditetapkan HIMAGHITA, dan lokasi kegiatan ini merupakan desa binaan HIMAGHITA. Oleh karena itu, HIMAGHITA dipastikan akan mendampingi terus menerus hingga tujuan dari program ini tercapai.

\section{HASIL PEMBAHASAN DAN DAMPAK}

A. Introduksi Teknologi Proses Produksi Olahan Tomat (Tomat

\section{Rasa Kurma)}

Program introduksi teknologi pengolahan tomat menjadi torakur (tomat rasa kurma) ini telah sukses dilaksanakan di Desa Wunut, Kabupaten Klaten oleh tim pengabdian dengan himpunan mahasiswa ITP UNS pada tanggal 13 Juni 2015 melalui kegiatan SAPA DESA 1. Masyarakat sangat antusias dengan kegiatan ini. Peserta yang hadir meliputi seluruh anggota Kelompok Tani Sumber Rejeki dan Kelompok Tani Wanita Dahlia. Kegiatan bertempat di Balai Desa Wunut, Kabupaten Klaten

Proses pembuatan torakur pada awalnya dicoba dengan berbagai variasi jenis gula yang digunakan, yaitu gula 
pasir, gula batu, dan gula aren. Hasil yang diperoleh menunjukkan torakur yang menggunakan campuran gula batu dan gula jawa menghasilkan torakur dengan rasa, warna, dan tekstur terbaik. Selain pelatihan proses pembuatan, pada tahap ini masyarakat juga dilatih dengan proses pengemasan. Pengemasan yang digunakan adalah pengemas mika, dengan label dibagian atasnya.

Produk torakur yang telah dihasilkan selanjutnya dilakukan analisa kadar air dan kandungan sukrosa pada bahan. Hasil pengujian menunjukkan kadar air torakur 25,96\%, sedangkan kadar sukrosa $17,84 \%$. Nilai ini menunjukkan bahwa kadar gula torakur tidak sebesar produk olahan menggunakan gula yang lain seperti dodol, geplak, serta manisan sehingga dapat mengurangi kekhawatiran konsumen yang diet terhadap gula untuk tetap dapat mengkonsumsinya.
B. Introduksi Teknologi Pengolahan

\section{Abon Cabai}

Program introduksi teknologi pengolahan cabai menjadi abon cabai ini ini telah sukses dilaksanakan di Desa Wunut, Kabupaten Klaten oleh tim pengabdian dengan himpunan mahasiswa ITP UNS pada tanggal 22 Agustus 2015 melalui kegiatan SAPA DESA 2. Peserta yang hadir meliputi seluruh anggota Kelompok Tani Sumber Rejeki dan Kelompok Tani Wanita Dahlia. Kegiatan bertempat di Desa Wunut, Kabupaten Klaten. Selain proses pengolahan, masyarakat juga diberikan pelatihan tentang proses pengemasan abon cabai. Abon cabai yang telah dihasilkan selanjutnya diuji kadar airnya. Hasil pengujian menunjukkan kadar air abon7,81 

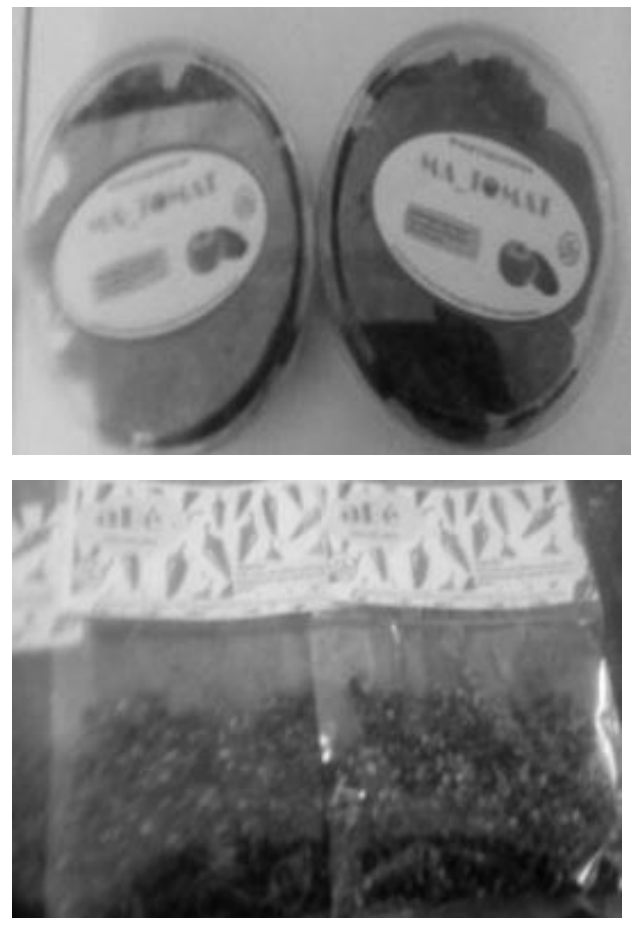

Gambar 1. Produk Abon Cabai (atas), Produk Torakur (bawah)

Pada program ini tim pengabdian sekaligus juga menghibahkan peralatan kepada kedua mitra meliputi blender untuk penggilingan cabai, plastic sealer untuk proses pengemasannya, dan cabinet dryer untuk proses pengeringan.

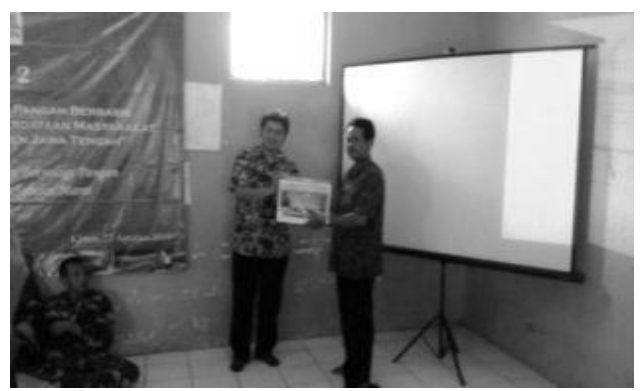

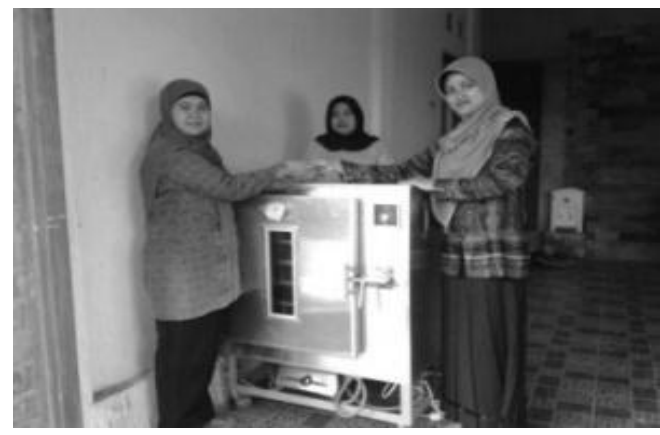

Gambar 2. Penyerahan Alat Produksi

$$
\text { Dengan adanya program }
$$

introduksi teknologi pengolahan ini, pengetahuan masyarakat Desa Wunut tentang teknologi pengolahan hasil pertanian semakin meningkat, khususnya pada proses pengolahan abon cabai dan torakur. Peralatan yang dihibahkan dapat membantu proses produksi yang akan dikembangkan. Pengolahan cabai menjadi abon dan tomat menjadi torakur mampu meningkatkan nilai jual kedua komoditas tersebut terutama saat panen hingga mencapai $30 \%$.

\section{Pelatihan Kewirausahaan dan Manajemen Industri Pangan \\ Pelatihan kewirausahaan dan} manajemen industri pangan ini 
dilaksanakan di Desa Wunut, Kabupaten Klaten oleh tim pengabdian dengan himpunan mahasiswa ITP UNS pada tanggal 30 Oktober 2015 melalui kegiatan SEJAGAD. Peserta yang hadir meliputi seluruh anggota Kelompok Tani Sumber Rejeki dan Kelompok Tani Wanita Dahlia. Kegiatan bertempat di Desa Wunut, Kabupaten Klaten. Dalam kegiatan ini diberikan penyuluhan tentang teknik pengembangan kewirausahaan serta sistem manajemen dalam industri pangan.Dalam pertemuan ini juga disepakati bahwa produk tomat rasa kurma serta abon cabai yang telah dihasilkan selanjutnya akan dicarikan P-IRT untuk mempermudah proses pemasaran. Produk torakur dan abon cabai awalnya akan dipasarkan di "Omah Telo" yaitu toko binaan prodi Ilmu dan Teknologi Pangan, yang berlokasi di Karanganyar.Proses pemasaran selanjutnya juga akan dikembangkan melalui pasar online.

\section{Pelatihan Pemasaran Berbasis TI} dan Strategi Direct Selling

Dalam kegiatan SEJAGAD selain memberikan training kewirausahaan dan manajemen industri pangan, masyarakat desa wunut khususnya yang tergabung dalam Kelompok Tani Sumber Rejeki dan Kelompok Tani Wanita Dahlia juga diberikan pelaihan pemasaran berbasis $\mathrm{TI}$ dan strategi direct selling. Masyarakat dibantu oleh tim BSO Himaghita, diajarkan untuk membuat blog dan website yang berfungsi sebagai toko online. Tipe pemasaran ini selanjutnya ditujukan untuk mendukung pemasaran produk torakur dan abon cabai di toko Program Studi Ilmu dan Teknologi Pangan yang diberi nama "Omah Telo".

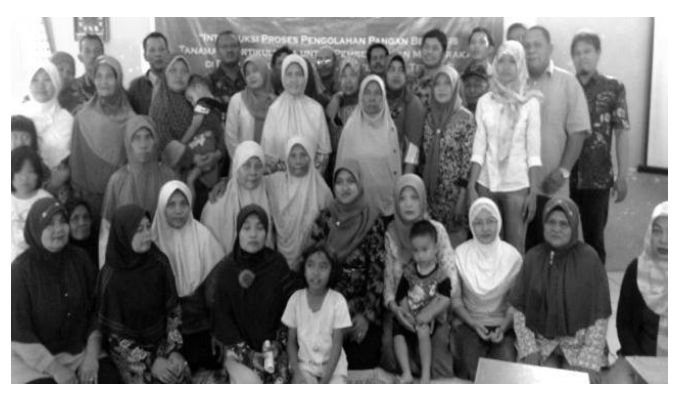

Gambar 3..Tim Pengabdian dan Mitra 


\begin{abstract}
Seluruh kegiatan yang
dilaksanakan dalam program IbM ini mampu meningkatkan kinerja

masyarakat Desa Wunut khususnya Kelompok Tani Sumber Rejeki dan Kelompok Tani Wanita Dahlia sehingga mampu menciptakan peluang usaha baru yang menjanjikan.
\end{abstract}

\section{KESIMPULAN}

1. Teknologi pengolahan tomat menjadi torakur (tomat rasa kurma) dan cabai menjadi abon cabai mampu meningkatkan nilai jual kedua komoditas tersebut terutama saat panen hingga mencapai $30 \%$.

2. Peralatan yang dihibahkan kepada mitra bermanfaat dalam proses produksi abon cabai maupun torakur.

3. Terjadi peningkatan kinerja masyarakat Desa Wunut khususnya Kelompok Tani Sumber Rejeki dan Kelompok Tani Wanita Dahlia sehingga mampu menciptakan peluang usaha baru yang menjanjikan.

\section{UCAPAN TERIMAKASIH}

Tim pengabdian kepada masyarakat mengucapkan terima kasih kepada PNBP UNS Tahun 2015 yang telah membiayai kegiatan pengabdian ini melalui skim IbM (Ipteks bagi Masyarakat) serta kepada Program Studi Ilmu dan Teknologi Pangan, Fakultas Pertanian dan Universitas Sebelas Maret.

\section{REFERENSI}

Anonim, 2016. Klaten Dalam Angka. Badan Pusat Statistik Kabupaten Klaten.

Dewanti, Tri, Widya Dwi Rukmi, Mochamad Nurcholis,dan Jaya Mahar Maligan, 2010. Aneka Produk Olahan Tomat dan Cabe. Jurusan Teknologi Hasil Pertanian. Fakultas Teknologi Pertanian. Universitas Brawijaya Malang.

Sudaro, Yani dan Dwi Ari Ratriningsih, 1999. Pengeringan Cabai. Penerbit Penebar Swadaya. Jakarta 


\section{BIODATA PENELITI}

Danar Praseptiangga, S.T.P., M.Sc., Ph.D.

Tenaga pendidik atau dosen pada program studi Ilmu dan teknologi Pangan Fakultas Pertanian Universitas Sebelas Maret Surakarta. Lulus Magister (S2) bidang food science and biotechnology di Hiroshima University Japan pada tahun 2009. Sedangkan gelar doktor (S3) diraih pada tahun 2012 dalam bidang ilmu food science and biotechnology pada Hiroshima University Japan. Saat ini menjabat sebagai Kepala Pusat Studi Jepang (PSJ) LPPM UNS serta Kepala Laboratorium Kimia Pangan dan Biokimia, Program Studi IImu dan Teknologi Pangan Fakultas Pertanian UNS. 